\title{
Reduced expression of E-cadherin and increased sialylation level in clear cell renal cell carcinoma
}

\author{
Małgorzata Borzym-Kluczyk ${ }^{1 凶}$, Iwona Radziejewska², Marzanna Cechowska-Pasko ${ }^{1}$ and \\ Barbara Darewicz ${ }^{3}$ \\ 1Department of Pharmaceutical Biochemistry; ${ }^{2}$ Department of Medical Chemistry; ${ }^{3}$ Department of Urology, Medical University of Bialystok, \\ Białystok, Poland
}

\begin{abstract}
Cancer cells are characterized by an aberrant increase in protein $\mathrm{N}$-glycosylation and by disruption of E-cadherinmediated adherens junctions. However, the relationship between alterations in $\mathrm{N}$-glycosylation process and loss of E-cadherin adhesion in cancer remains unclear. The mechanisms of altered expression of adhesive glycoproteins in cancer cells have not been fully elucidated. Thus, the aim of this study was to examine the expression of E-cadherin and sialyl Lewisa/x, NeuAca2-3Gal, NeuAca26Gal/GalNAc structures in the normal renal tissue and intermediate and cancerous tissues from patients with clear cell RCC. Moreover, we attempted to correlate the E-cadherin expression with some specific sugar residues of renal cancer tissue glycoproteins. The expression of E-cadherin was analysed using ELISA test and immunoblotting. Oligosaccharide structures and sialylation level were detected with ELISA test using specific biotinylated lectins or antibodies. A significant decrease of E-cadherin expression as well as a significant increase in sialylated oligosaccharides level in intermediate zone and renal cancer tissue in comparison to normal renal tissue are reported. Significant decrease in expression of cadherins and increase in sialylation of oligosaccharide structures in renal cancer tissue in comparison to normal renal tissue, and in renal cancer tissue in comparison to intermediate zone of renal tissue, are important for the future research concerning detection and quantification of cadherins and sialylated oligosaccharide structures in urine and cells of urinary sediment as possible non-invasive marker of early RCC.
\end{abstract}

Key words: clear cell renal cell carcinoma; E-cadherin; lectins; sialyl Lewis antigens

Received: 24 November, 2015; revised: 29 March, 2016; accepted: 19 February, 2017; available on-line: 24 July, 2017

e-mail: gocha@umb.edu.pl, malgorzata.borzym-kluczyk@umb. edu.pl

Abbreviations: BSA, bovine serum albumin; $C \mathrm{CRCC}$, clear cell renal cell carcinoma; ELISA, enzyme-linked immunosorbent assay; Gal$\mathrm{NAc}, \mathrm{N}$-acetylgalactosamine; GlcNAc, N-acetylglucosamine; MAA Maackia amurensis agglutinin; NeuAc, sialic acid; sLewisa, sialyl Lewis antigen; sLewis ${ }^{x}$, sialyl Lewis ${ }^{x}$ antigen; SNA, Sambucus nigra agglutinin; TACAs, tumor associated carbohydrate antigens

\section{INTRODUCTION}

Renal cell carcinoma (RCC) is the most common type of kidney cancer in adults. It has been reported that, in the USA, RCC accounts for approximately $3 \%$ of adult malignancies and $90-95 \%$ of neoplasms originating from the kidney (Gupta \& Spiess, 2013). Despite the development of a number of modern diagnostic methods, the
RCC is usually diagnosed after invasion into surrounding tissues and organs. The invasion of RCC include cells decompaction and migration. Renal cells are compacted mostly by homophilic adhesion mediated by classical cadherins of adherens junction or by non-classical adherins (desmogleins and desmocollins) of desmosomal junctions that bind renal cells together, and by integrins that bind renal cells to extracellular matrix (Alberts et al., 2008; Syed et al., 2002; Stemmler, 2008). It was revealed that antibodies against E-cadherin blocked compaction, whereas antibodies against other cell-surface proteins did not. The cadherin superfamily in humans includes more than $180 \mathrm{Ca}^{2+}$-dependent, membrane anchored, external, heavily N-glycosylated glycoproteins (Syed et al., 2002; Pinho et al., 2011; Paulson et al., 2014). While extracellular N-terminal tips of cadherin molecules on neighboring renal cells mediate highly selective homophilic Velcro type of adhesion in these cells, cytoplasmic tail of classical adherins binds to actin in adherens junctions and cytoplasmic tails of non-classical adherins bind to intermediate filaments (Leckband \& de Rooij, 2014; McEwen et al., 2012). It was reported that mutations, disrupting the production or function of cadherins, facilitated invasion of the cancerous cells into the neighboring tissues, because mutated cancer cells had both E-cadherinmediated adhesion and desmosomal junctions disrupted (Leckband \& Israelachvili, 2001; Berx \& van Roy, 2009; Giepmans \& van Ijzendoorn 2009). The separation of renal cells may be facilitated by increased surface glycan sialylation, that increases repulsion induced by negative charge of dissociated carboxyl groups of sialic acids. Increased branching of $\mathrm{N}$-glycans on the surface of the cells with decreased fucosylation are among important factors determining metastatic potential of the cells (Varki \& Freeze, 2009; Lange et al., 2014; Zhao et al., 2008). However, the relationship between altered N-glycosylation, as well as sialylation and loss of E-cadherin adhesion in RCC remains unclear. Thus, the aim of this study was to examine the expression of E-cadherin and sialyl Lewis ${ }^{a}$, sialyl Lewis ${ }^{x}$, NeuAc $\alpha 2-3 G a l$, NeuAc $\alpha 2-$ $6 \mathrm{Gal} / \mathrm{GalNAc}$ structures in normal renal tissue and intermediate and cancerous tissue from patients with clear cell RCC. Moreover, we made the attempt to correlate the expression of E-cadherin with sialic acid-containing structures of the glycoproteins in above-mentioned three areas of renal tissue.

\section{MATERIALS AND METHODS}

Ethical approval. All procedures performed during the studies involving human participants were in accord- 
Table 1. Fuhrman nuclear grade, TNM stage and size of examined tumors

\begin{tabular}{|c|c|c|c|c|}
\hline Patients & $n=35$ & & & \\
\hline Fuhrman Nuclear Grade & $\begin{array}{l}\text { G1 } \\
4\end{array}$ & $\begin{array}{l}\mathrm{G} 2 \\
22\end{array}$ & $\begin{array}{l}\text { G3 } \\
4\end{array}$ & $\begin{array}{l}\text { G4 } \\
5\end{array}$ \\
\hline TNM Stage, Size & $\begin{array}{l}\mathrm{T} 1-17 \\
4-7 \mathrm{~cm}\end{array}$ & $\begin{array}{l}T 2-14 \\
7 \geq 10 \mathrm{~cm}\end{array}$ & $\begin{array}{l}\text { T3- } 2 \\
\text { All tumors extended into major } \\
\text { veins or peripheric tissues }\end{array}$ & $\begin{array}{l}\text { T4- } 2 \\
\text { Tumor invaded beyond Gerota's } \\
\text { fascia }\end{array}$ \\
\hline Nodes & No & NO & NO & N1 \\
\hline Metastases & $M X$ & $M X$ & $M X$ & $M X$ \\
\hline
\end{tabular}

Table 2. Binding specificity of lectins and monoclonal antibodies

\begin{tabular}{ll}
\hline Lectins & Binding preference \\
\hline $\begin{array}{l}\text { Maackia amurensis } \\
\text { (MAA) }\end{array}$ & NeuAca2-3Gal \\
\hline $\begin{array}{l}\text { Sambucus nigra } \\
\text { (SNA) }\end{array}$ & NeuAca2-6Gal/GalNAc \\
\hline Monoclonal antibodies & Binding preference \\
\hline sialyl Lewis & NeuAca2-3Gal $\beta 1-3($ Fuca1-4)GlcNAc $\beta$ \\
sialyl Lewis & NeuAca2-3Gal $\beta 1-4($ Fuca1-3)GlcNAc $\beta$ \\
\hline
\end{tabular}

ance with the ethical standards of the institutional and/ or national research committee and with the 1964 Helsinki declaration and its later amendments or comparable ethical standards.

Patients. The study was performed on renal tissues taken from 35 patients (17 females and 18 males) with clear cell RCC, hospitalized at the Department of Urology, Medical University of Bialystok, Poland. Diagnosis was confirmed by histopathological assessment in the Department of Pathological Anatomy, Medical University of Bialystok. The age of patients ranged from 54 to 75 years (mean 60 years). Kidneys removed during complete nephrectomy, were sectioned along their long axis through the center of the tumor. Tumor size, Fuhrman nuclear grade, and TNM stage are presented in the Table 1. Tissue samples $(2 \times 2 \times 2 \mathrm{~cm})$ were taken from the tumor, an intermediate zone adjacent to tumor tissue, and normal renal cortex/medulla unoccupied by the tumor. Tissue samples were stored at $-70^{\circ} \mathrm{C}$.

Preparation of tissue extract. The $10 \%$ (w/v) tissue homogenates were prepared in $0.1 \mathrm{M}$ citric buffer, $\mathrm{pH} 4.3$ supplemented with protease inhibitors (Sigma, St Louis, MO, USA) using Ultra-Turrax T8 homogenizer $\left(2 \mathrm{~min}, 4^{\circ} \mathrm{C}\right)$ and centrifuged $\left(20 \mathrm{~min}, 10000 \times g, 4^{\circ} \mathrm{C}\right)$. Supernatants, after concentration in Centriprep C30 concentrators (Amicon, Millipore, Bedford, MA, USA), were applied on Sephadex G-10 column and eluted with water. Collected $2 \mathrm{~mL}$-fractions containing protein (absorbance at $280 \mathrm{~nm}$ ) were collected and re-concentrated by few centrifugations using Centripreps C30 (60 min $1500 \times g)$. The supernatants containing $40-60 \mathrm{mg}$ of protein/mL were further analyzed.

Sialylated sugar determination with lectins. To analyze the sialylation level of glycoproteins in renal cell extracts, ELISA test with biotinylated lectins (Vector, Burlingame, USA) was performed as previously described (Borzym-Kluczyk et al., 2015). The binding specificity of lectins is presented in the Table 2. Briefly, samples were diluted with phosphate-buffered saline, $\mathrm{pH}$ 7.4 (PBS) to protein concentration $5 \mu \mathrm{g} / \mathrm{mL}$. Microtiter plates (NUNC F96; Maxisorp, Roskilde, Denmark) were coated with samples (50 $\mu \mathrm{L} /$ well), overnight, at room temperature. All the following steps were performed at room temp. The plates were washed 3 times with $100 \mu \mathrm{L}$ of PBS, containing 0.05\% Tween 20 (PBS-T), between all ensuing steps. Unbound sites were blocked with $100 \mu \mathrm{L}$ of $1 \%$ blocking reagent (Roche Diagnostics, Mannheim, Germany) for $1 \mathrm{~h}$ and incubated for $1 \mathrm{~h}$ with $100 \mu \mathrm{L} /$ well of biotinylated lectins $(0.5 \mu \mathrm{g} /$ $\mathrm{mL}$ in PBS-T containing $1 \%$ bovine serum albumin (PBS-T-BSA), (BSA - Sigma, St Luis, MO, USA)). Lectin solutions were supplemented: for SNA lectin with $0.1 \mathrm{mmol} / \mathrm{L} \mathrm{CaCl}_{2}$; for MAA lectin with $0.1 \mathrm{mmol} / \mathrm{L}$ $\mathrm{CaCl}_{2}$ and $0.01 \mathrm{mmol} / \mathrm{L} \mathrm{MnCl}_{2}$. After washing, microtiter plates were incubated with $100 \mu \mathrm{L} /$ well of horseradish peroxidase-conjugated avidin D (Vector, Burlingame, CA, USA) (1:2500) in PBS-T-BSA, for $1 \mathrm{~h}$. After washing 4 times with PBS colored reaction with $100 \mu \mathrm{L} /$ well of 2,2'-azino-bis(3-ethylbenzthiazoline-6-sulfonic acid) (Sigma, St Luis, MO, USA) was developed for $45 \mathrm{~min}$ and spectrophotometric measurements were performed at $405 \mathrm{~nm}$, using an Infinite $\mathrm{M}_{200}$ microplate reader (Tecan, Salzburg, Austria) with control samples containing BSA instead of tissue extracts.

Protein concentration assay. Protein concentrations were determined using the bicinchoninic acid (BCA) test according to the method (Smith et al., 1985). Bovine serum albumin was used as a standard.

E-cadherin and Lewis antigens determination. The expression of E-cadherin and Lewis antigens of glycoproteins in renal cell extracts in normal, intermediate

Table 3. The source and final dilutions of antibodies used in this study

\begin{tabular}{|c|c|c|c|}
\hline Antibody & Clone & Source & Final dilution \\
\hline E-cadherin & sc-7870 & Santa Cruz Biotechnology & $1: 500$ \\
\hline sialyl Lewis & KM231 & Millipore & $1: 500$ \\
\hline sialyl Lewisa & KM93 & Millipore & $1: 200$ \\
\hline Horseradish peroxidase-conjugated anti-rabbit lgG & - & Sigma & $1: 1500$ \\
\hline Horseradish peroxidase-conjugated anti-mouse IgM & - & Sigma & $1: 1000$ \\
\hline Horseradish peroxidase-conjugated anti-mouse IgG & - & Sigma & $1: 1000$ \\
\hline
\end{tabular}




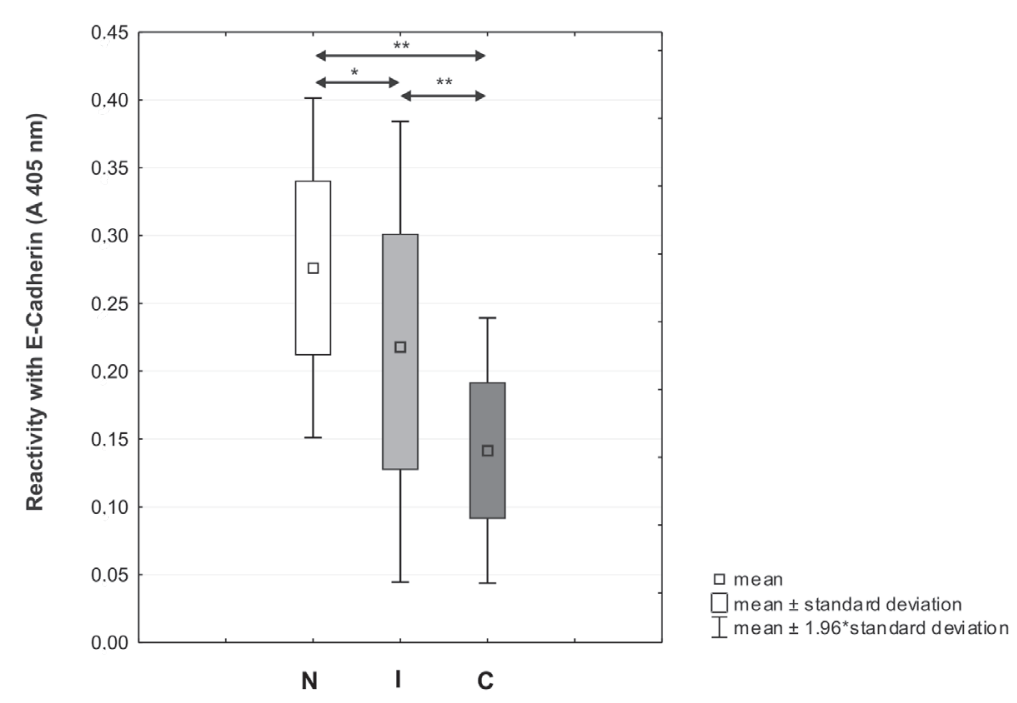

Figure 1. Expression of E-cadherin in extracts of normal (N), intermediate zone adjacent to tumor (I) and renal cancer tissue (C).

Data are presented as mean \pm S.D. Statistical significance was considered as the level of $p \leq 0.05^{*} ; p \leq 0.01^{* *}(n=35)$. Statistical analysis of the data was carried out using one way analysis of variance (ANOVA) followed by NIR test for post hoc analysis.

zone adjacent to tumor tissue and cancer renal tissue were analyzed using ELISA test. The binding specificity of applied monoclonal antibodies is presented in the Table 2. The sources and dilutions of applied antibodies are presented in the Table 3.

Preparation of microtiter plates including coating with tissue extracts, washing and blotting was performed as above. Then the microtiter plates were incubated for $1 \mathrm{~h}$ with $100 \mu \mathrm{L} /$ well of primary monoclonal or polyclonal antibody $(0.5 \mu \mathrm{g} / \mathrm{mL}$ in PBS-T) (Table 3), washed, and incubated with horseradish peroxidase-conjugated secondary antibody: anti-mouse IgG (for anti-sialyl Lewis ${ }^{\text {) }}$, anti-mouse IgM (for anti-sialyl Lewis ${ }^{x}$ ) or anti-rabbit IgG (for anti-E-cadherin). After washing the colored reaction was developed as described above.

Polyacrylamide gel electrophoresis (SDS/PAGE). Samples of renal tissue extracts, containing $15 \mu \mathrm{g}$ of protein, were subjected to SDS-PAGE, as described by Laemmli (1970). The electrophoresis was run for 50-60 minutes. In each experiment $7.5 \%$ polyacrylamide gel and constant current $(25 \mathrm{~mA})$ were used.

Immunoblotting. After electrophoresis samples were transferred to nitrocellulose membranes (Bio-Rad, Hercules, USA), and nonspecific binding was blocked with $5 \%$ solution of milk (Sigma, St Luis, MO, USA). Membranes were probed with primary rabbit anti-E-cadherin antibody $(1: 500)$ for $16 \mathrm{~h}$ at $4^{\circ} \mathrm{C}$. Next, the membranes were immersed in alkaline phosphatase-conjugated antibody against whole molecule of rabbit $\operatorname{IgG}(1: 1000)$ in TBS-T, for $1 \mathrm{~h}$, with shaking, washed with TBS-T (5x for $5 \mathrm{~min}$ ) and exposed to BCIP/NBT reagent (SigmaFast). Densitometric analysis of protein bands on nitrocellulose membrane was performed using GeneTools image software (Syngene).

Statistical analysis. Statistical analyses were performed using Statistica 10 (StatSoft, Cracow, Poland) using Student's test, ANOVA and post hoc test. Results are expressed as means \pm S.D. Statistical significance was defined as $p<0.05$. The correlation between E-cadherin and all examined sugar structures levels in the three analyzed areas (normal, intermediate and cancer) of renal tissue were also calculated. To express correlation evalu- ated by Pearson's coefficient we used the following degrees: $r=1$ perfect correlation; $r=0.75 \leq 1$ high degree of correlation; $r=0.30 \leq 0.75$ moderate degree of correlation; $r=0.1 \leq 0.30$ weak degree of correlation. Statistical significance at $* p<0.05$.

\section{RESULTS}

Figure 1 shows E-cadherin polyclonal antibody reactivity with extracts of normal, intermediate and cancer renal cortex/medulla tissues. We observed a significant decrease of E-cadherin expression in intermediate zone and in renal cancer tissue in comparison to normal renal tissue, and in renal cancer tissue in comparison to intermediate zone of renal tissue.

Figure 2 shows Western blot analysis (A) and densitometric analysis (B) of E-cadherin expression in extracts of normal, intermediate and cancer renal cortex/ medulla tissue. We observed a decrease in E-cadherin expression in extracts of intermediate and cancer tissues in comparison to normal renal tissue.

Figure 3 shows the expression of oligosaccharide structures on glycoproteins of renal tissue extracts in normal, intermediate and cancer tissue. We revealed significantly higher expression of NeuAc $\alpha 2-3 \mathrm{Gal}$ structures (detected by MAA lectin) in cancer and intermediate renal tissue, as compared to normal tissue. The expression

\section{A}

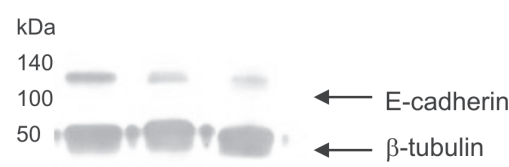

N I C

B

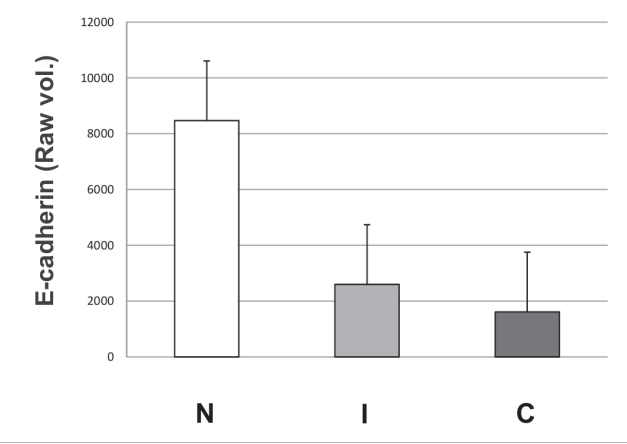

Figure 2. Western blot (A) and densitometric analysis (B) of Ecadherin expression in extracts of normal $(N)$, intermediate (I) and cancer (C) renal cortex/medulla tissue.

Samples containing $15 \mu \mathrm{g}$ of protein were submitted to electrophoresis and immunoblotting. Western blot from one of three independent experiments is presented (A). Mean values of densitometric analysis from three independent experiments \pm S.D. are presented (B). 


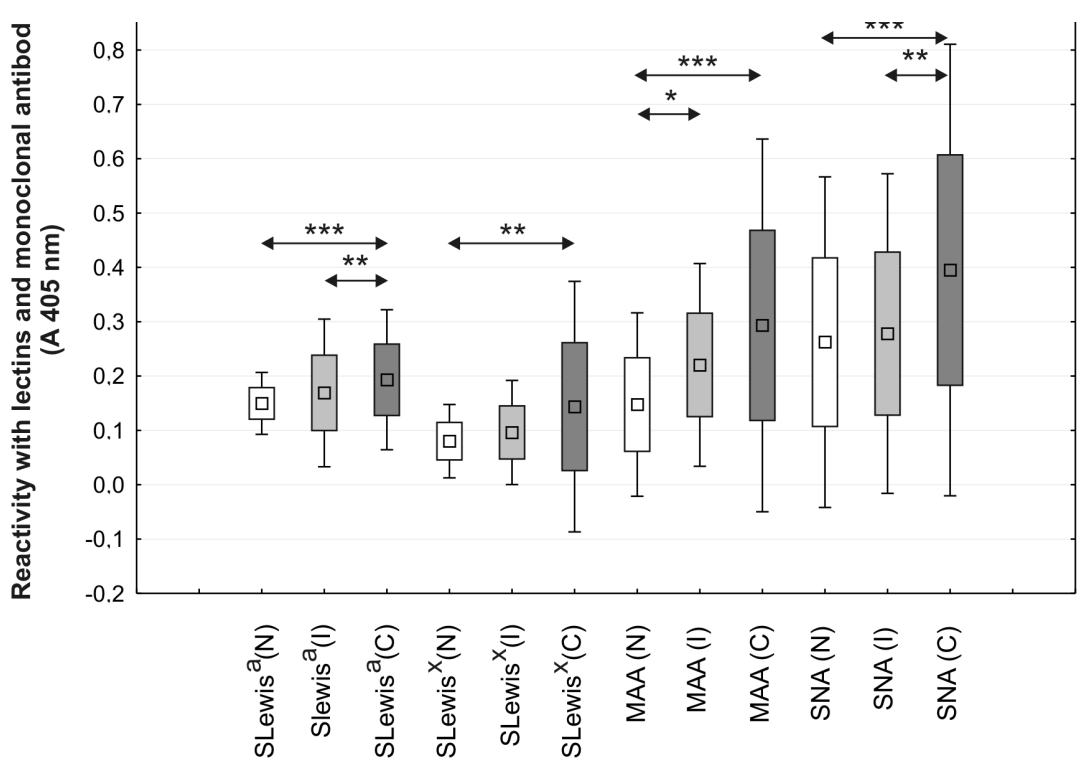

Figure 3. The expression of sialylated sugar antigens on glycoproteins in normal (N), intermediate $(\mathrm{I})$ and cancer $(\mathrm{C})$ renal cortex/medulla tissue, detected with biotinylated lectins and monoclonal antibodies.

Data are presented as mean \pm S.D. Statistical significance was considered as the level of $\left.p \leq 0.05^{*} ; p \leq 0.01^{* *} ; p \leq 0.001^{* * *}\right)(n=35)$. Statistical analysis of the data was carried out using one way analysis of variance (ANOVA) followed by NIR test for post hoc analysis.

of NeuAc $\alpha 2-6 \mathrm{Gal} / \mathrm{GalNAc}$ (detected by SNA lectin) and NeuAc $\alpha 2-3$ Gal $\beta 1-3$ (Fuc $\alpha 1-4)$ GlcNAc $\beta$ - (detected by sialyl Lewis ${ }^{a}$ antibody) was significantly higher in extracts of cancer tissue in comparison to normal and intermediate renal tissues. The expression of NeuAc $\alpha 2-3 \mathrm{Gal} \beta 1-$ 4(Fuc $\alpha 1-3)$ GlcNAc $\beta$ - structures (detected by sialyl Lewis ${ }^{x}$ antibodies) was significantly higher in cancer tissue in comparison to normal tissue.

Table 4. Correlation coefficients of the E-cadherin expression versus the expression of examined structures.

E-cadherin expression was correlated with the following structures: NeuAca2-3Gal (detected by MAA lectin), NeuAca2-6Gal/GalNAc (detected by SNA lectin) and sialyl Lewis $/ x$ antigens (detected by sialyl Lewis a and sialyl Lewis ${ }^{\times}$antibodies) in extracts of normal (N), intermediate (I) and cancer (C) renal tissue. ${ }^{*} p<0.05$

\begin{tabular}{|c|c|c|c|}
\hline \multirow{2}{*}{ Structure/area } & \multicolumn{3}{|c|}{$\begin{array}{c}\text { Pearson's coefficient values } \\
\text { E-cadherin }\end{array}$} \\
\hline & Normal N & Intermediate I & Cancer C \\
\hline NeuAca2-3Gal/N & 0.045 & -0.05 & -0.08 \\
\hline NeuAca2-3Gal// & -0.11 & 0.01 & -0.10 \\
\hline NeuAca2-3Gal/C & -0.06 & $-0.38^{*}$ & -0.10 \\
\hline $\begin{array}{l}\text { NeuAca2-6Gal/ } \\
\text { GalNAc/N }\end{array}$ & 0.04 & 0.16 & -0.06 \\
\hline $\begin{array}{l}\text { NeuAca2-6Gal/ } \\
\text { GalNAc/l }\end{array}$ & 0.22 & 0.04 & 0.06 \\
\hline $\begin{array}{l}\text { NeuAca2-6Gal/ } \\
\text { GalNAc/C }\end{array}$ & -0.11 & -0.20 & 0.03 \\
\hline sialyl Lewisa $/ \mathrm{N}$ & -0.06 & $-0.34^{*}$ & -0.03 \\
\hline sialyl Lewisa /l & -0.22 & -0.19 & -0.19 \\
\hline sialyl Lewisa /C & -0.01 & -0.13 & -0.24 \\
\hline sialyl Lewis×/N & 0.04 & 0.09 & 0.03 \\
\hline sialyl Lewis×/l & -0.09 & 0.01 & 0.01 \\
\hline sialyl Lewis×/C & 0.24 & -0.18 & -0.31 \\
\hline
\end{tabular}

Table 4 shows correlation coefficients of E-cadherin expression versus expression of sialylated oligosaccharide structures on glycoproteins in renal tissue extracts in normal, intermediate and cancer tissue. We observed significant, moderate negative correlations between E-cadherin in intermediate renal tissue and expression of NeuAc $\alpha 2-3 G a l$ structures in cancer tissues and sialyl Lewis ${ }^{a}$ in normal tissues.

Figure 4 shows Pearson coefficient variation between E-cadherin in intermediate renal tissue and expression of NeuAc $\alpha 2-3 \mathrm{Gal}$ structures in cancer tissues (A) and sialyl Lewis ${ }^{a}$ structure expression in normal renal tissue (B). Values between -0.3 and -0.7 indicate moderate negative correlations.

\section{DISCUSSION}

Most RCC develop from the epithelium of renal tubules. The possibilities and results of surgical RCC treatment depend on the stage of malignancy. The tumors at I and II stage, limited to the kidney are relatively easy to remove via surgical eradication, but it is much more difficult to cure the RCC metastases. In our research we found significant decrease of E-cadherin expression in intermediate tissue as compared to normal tissue, and in cancerous tissue as compared to normal and intermediate renal tissue. The abovementioned results were confirmed with Western blot and qualitative analysis of E-cadherin expression, which strongly support the thesis considering the decompaction as a preliminary step in RCC invasion.

Other authors revealed significance of E-cadherin expression level as a potential factor that could be used in cancer diagnosis (Truong \& Shen, 2011). Gervais et al., 2007 observed the decrease of the protein expression in cancerous tissues suggesting its application as potential valuable prognostic marker in clear cell RCC. However, there are also contradictory reports. Ronkainen et al., 2010 stated, that the nuclear or membranous expression of E-cadherin was not a prognostic factor for RCC-dependent survival. It was reported that mutations that disrupt the production or function of E-cadherin are often found in cancer cells and promote the development of malignancy (Varelas et al., 2014).

Renal cell compaction depends not only on cadherins, but also on their sugar structures carrying a plethora of information, due to a variety of sugar composition, branching, location and anomeric forms of cognate sugars (Thedieck et al., 2005; Langner et al., 2004). It is well established that many human tumor-associated antigens are the result of aberrant glycosylation of cell surface glycoproteins (Durand \& Seta, 2000; Hakomori, 1989). Increase in self-repelling of two cancerous cells may be caused by negatively charged sialic acids that frequently occupy the terminal, non-reducing position on glycan chains on membrane glycoproteins and glycolipids forming so called tumor associated carbohydrate antigens (TACAs). TA- 


\section{A}

scatter diagram:

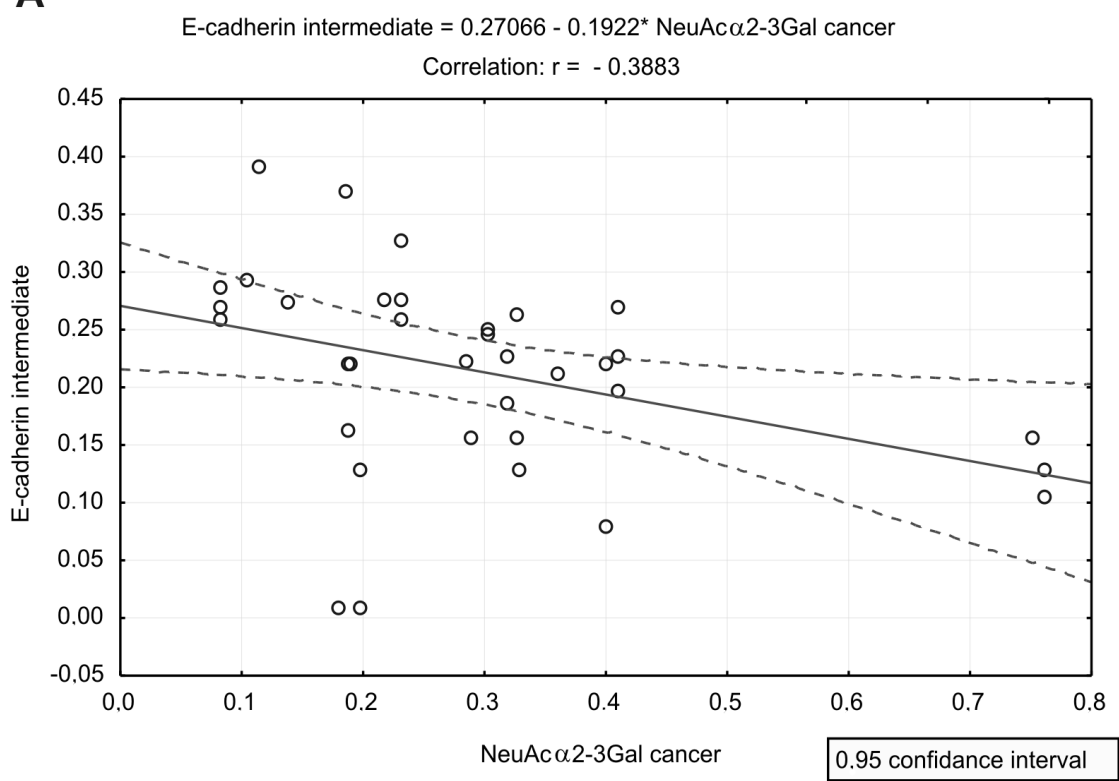

B

scatter diagram:

Sialyl Lewis ${ }^{\text {a }}$ normal vs E-cadherin intermediate E-cadherin intermediate $=0.36745-1.023^{*}$ Sialyl Lewis ${ }^{a}$ normal

Correlation: $r=-0.3435$

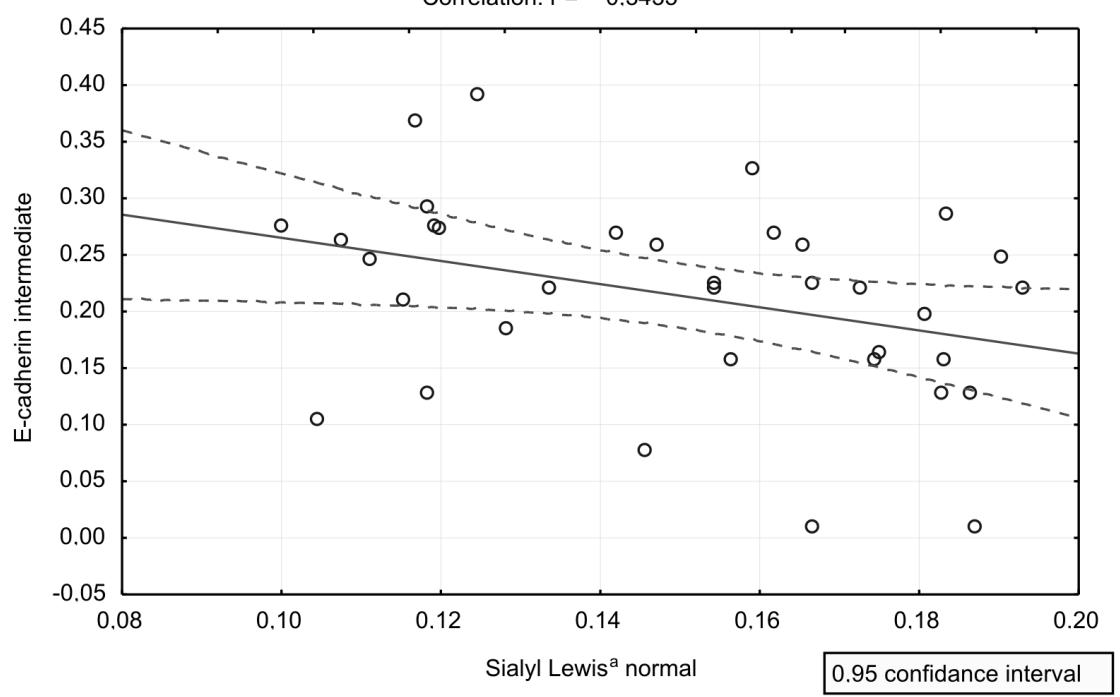

Figure 4. Pearson coefficient of statistically significant variation between the expression of E-cadherin and NeuAca2-3Gal structures in cancer tissues (A) and between expression of E-cadherin and sialyl Lewisa structure in normal renal tissue (B).

CAs found in both $\mathrm{N}$-and O-linked oligosaccharides of glycoproteins can be divided into subgroups e.g.: sialyl Lewis ${ }^{a}$ (NeuAc $\alpha 2-3$ Gal $\beta 1-3($ Fuc $\left.\alpha 1-4) G 1 c N A c \beta-\right)$ and sialyl Lewis ${ }^{x}$ (NeuAc $\alpha 2-3$ Gal $\beta 1-4($ Fuc $\alpha 1-3)$ GlcNAc $\beta$-) (Hakomori, 1984). In our studies we demonstrated an increase in sialylated Lewis antigens as well as NeuAc $\alpha 2-6 \mathrm{Gal} / \mathrm{GalNAc}$ and NeuAc $\alpha 2-3 \mathrm{Gal}$ structures in cancerous and intermediate zones in comparison to normal tissues. In our previous works we revealed similar, increasing tendencies of the expression of some specific sugar antigens, e.g. Lewis blood group antigens or MUC1 mucin (Borzym-Kluczyk \& Radziejewska, 2013; Borzym-Kluczyk et al., 2015; Borzym-Kluczyk et al., 2012).
Cancer cells often exhibit sialyl Lewis ${ }^{\mathrm{x}}$ and other selectin ligands on their surfaces. It is sought that these ligands play a role in the invasion and metastasis of cancer cells. Obtained values of Pearson's coefficient support the general tendency emerging from our results: whereas E-cadherin expression in RCC decreases, the sialylation level rises.

It has to be emphasized, that our results should be treated as preliminary due to limited number of evaluated cases. On the basis of observation that renal tubular cells exfoliate into urine, we suggest that our results may direct future research to the detection and quantification of cadherins in concentrated urine and/or urine sediment, as possible non-invasive marker of early cc RCC. 


\section{Acknowledgement}

This study was conducted with the use of equipment purchased by Medical University of Bialystok as part of the OP DEP 2007-2013 Priority Axis I.3, contract No. POPW.01.03.00-20-008/09

\section{Conflict of interest}

The authors declare no conflict of interest.

\section{REFERENCES}

Alberts B, Johnson A, Lewis J, Raff M, Roberts K, Walter P (2008) Molecular Biology of the Cell, 5 th edn, Garland Science, Taylor \& Francis Group, NY USA \& Abingdon UK.

Berx G, van Roy F (2009) Involvement of members of the cadherin superfamily in cancer. Cold Spring Harb Perspect Biol 1: a003129. doi: 10.1101/cshperspect.a003129

Borzym-Kluczyk M, Radziejewska I (2013) Changes of the expression of Lewis blood group antigens in glycoproteins of renal cancer tissues. Acta Biochim Pol 60: 223-226

Borzym-Kluczyk M, Radziejewska I, Cechowska-Pasko M (2015) Increased expression of MUC1 and sialyl Lewis antigens in different areas of clear renal cell carcinoma. Clin Exp Nephrol 19: 732-737. doi: 10.1007/s10157-014-1013-y

Borzym-Kluczyk M, Radziejewska I, Darewicz B (2012) Glycosylation of proteins in healthy and pathological human renal tissues. Folia Histochem Cytobiol 50: 599-604. doi: 10.5603/17895

Durand G, Seta N (2000) Protein glycosylation and diseases: blood and urinary oligosaccharides as markers for diagnosis and therapeutic monitoring. Clin Chem 46: 795-805

Gervais ML, Henry PC, Saravanan A, Burry TN, Gallie BL, Jewett MA, Hill RP, Evans AJ, Ohh M. (2007) Nuclear E-cadherin and VHL immunoreactivity are prognostic indicators of clear-cell renal cell carcinoma. Lab Invest 87: 1252-1264.doi: 10.1038/labinvest.3700684

Giepmans BN, van Ijzendoorn SC (2009) Epithelial cell-cell junctions and plasma membrane domains. Biochim Biophys Acta 1788: 820-831. doi: 10.1016/j.bbamem.2008.07.015

Gupta S, Spiess PE (2013) The prospects of pazopanib in advanced renal cell carcinoma. Ther Adv Urol 5: 223-232. doi: $10.1177 / 1756287213495099$

Hakomori S (1989) Aberrant glycosylation in tumors and tumor-associated carbohydrate antigens. Adv Cancer Res 52: 257-331

Hakomori S (1984) Tumor-associated carbohydrate antigens. Annu Rev Immunol 2: 103-126. doi:10.1146/annurev.iy.02.040184.000535

Laemmli, U K (1970) Cleavage of structural proteins during the assembly of the head of bacteriophage T4. Nature 227: 680-685

Lange T, Samatov TR, Tonevitsky AG, Schumacher U (2014) Importance of altered glycoprotein-bound $\mathrm{N}$ - and O-glycans for epitheli- al-to-mesenchymal transition and adhesion of cancer cells. Carbohydr Res 389: 39-45. doi: 10.1016/j.carres.2014.01.010.

Langner C, Ratschek M, Rehak P, Schips L, Zigeuner R (2004) Expression of MUC1 (EMA) and E-cadherin in renal cell carcinoma: a systematic immunohistochemical analysis of 188 cases. Mod Pathol 17: $180-188$. doi: $10.1038 /$ modpathol.3800032

Leckband D, Israelachvili J (2001) Intermolecular forces in biology. Q Rev Biophys 34: 105-267

Leckband DE, de Rooij J (2014) Cadherin adhesion and mechanotransduction. Annu Rev Cell Dev Biol 30: 291-315. doi: 10.1146/annurev-cellbio-100913-013212

McEwen AE, Escobar DE, Gottardi CJ (2012) Signaling from the adherens junction. Subcell Biochem 60: 171-196. doi: 10.1007/978-94007-4186-7_8

Paulson AF, Prasad MS, Thuringer AH, Manzerra P (2014) Regulation of cadherin expression in nervous system development. Cell $A d h$ Migr 8: 19-28. doi: $10.4161 /$ cam.27839

Pinho SS, Seruca R, Gärtner F, Yamaguchi Y, Gu J, Taniguchi N, Reis CA (2011) Modulation of E-cadherin function and dysfunction by N-glycosylation. Cell Mol Life Sci 68: 1011-1020. doi: 10.1007/ s00018-010-0595-0

Ronkainen H, Kauppila S, Hirvikoski P, Vaarala MH (2010) Evaluation of myosin VI, E-cadherin and beta-catenin immunostaining in renal cell carcinoma. J Exp Clin Cancer Res 29: 2. doi: 10.1186/1756-9966$29-2$

Smith PK, Krohn RI, Hermanson GT, Mallia AK, Gartner FH, Provenzano MD, Fujimoto EK, Goeke NM, Olson BJ, Klenk DC (1985) Measurement of protein using bicinchoninic acid. Anal Biochem 150: 76-85

Stemmler MP (2008) Cadherins in development and cancer. Mol Biosyst 4: 835-850. doi: 10.1039/b719215k

Syed SE, Trinnaman B, Martin S, Major S, Hutchinson J, Magee AI (2002) Molecular interactions between desmosomal cadherins. Biochem J 362: 317-327

Thedieck C, Kuczyk M, Klingel K, Steiert I, Müller CA, Klein G (2005) Expression of Ksp-cadherin during kidney development and in renal cell carcinoma. Br J Cancer 92: 2010-2017. doi: 10.1038/ sj.bjc. 6602597

Truong LD, Shen SS (2011) Immunohistochemical diagnosis of renal neoplasms. Arch Pathol Lab Med 135: 92-109. doi: 10.1043/20100478-RAR.1

Varelas X, Bouchie MP, Kukuruzinska MA (2014) Protein N-glycosylation in oral cancer: dysregulated cellular networks among DPAGT1, E-cadherin adhesion and canonical Wnt signaling. Glycobiology 24: 579-591. doi: 10.1093/glycob/cwu031

Varki A, Freeze HH (2009) Glycans in acquired human diseases. In Essentials of Glycobiology. Varki A, Cummings RD, Esko JD, Freeze $\mathrm{HH}$, Stanley P, Bertozzi CR, Hart GW, Etzler ME, eds. Cold Spring Harbor (NY): Cold Spring Harbor Press

Zhao YY, Takahashi M, Gu JG, Miyoshi E, Matsumoto A, Kitazume S, Taniguchi N (2008) Functional roles of N-glycans in cell signaling and cell adhesion in cancer. Cancer Sci 99: 1304-1310. doi: 10.1111/j.1349-7006.2008.00839.x 